\title{
Changing clinical picture of endemic Burkitt's lymphoma with improved diagnostic technology: A systematic review
}

\author{
Kamulegeya Adriane ${ }^{1,2, *}$, Louis Muwazi ${ }^{1}$, Oliver Press ${ }^{3}$ and Jackson Orem ${ }^{2,4}$ \\ ${ }^{1}$ Makerere University College of health Sciences, Kampala, Uganda \\ 2 Hutchinson's Cancer Research Institute Uganda, Kampala, Uganda \\ ${ }^{3}$ Fred Hutchinson Cancer Research Center and University of Washington Seattle, USA \\ ${ }^{4}$ Uganda Cancer Institute, Kampala, Uganda
}

\begin{abstract}
We evaluated the changes in anatomical locations of endemic Burkitt's lymphoma (eBL) by systematic review. We compared the reports before ultrasound became a routine investigation in Burkitt's lymphoma (BL) diagnosis with those that used ultrasound as part of pre therapeutic diagnosis. Methods: All alternative match terms able to capture the anatomical distribution of eBL were used as search terms for two electronic databases, namely Medline and "Web of Science". Only reports that had reasonable case load were considered for analysis. However the case reports and case series with five or less patients were not included. Results: Medline produced more systematic review identified reports. The search terms "endemic Burkitt lymphoma Africa" yielded the highest number of articles in both databases but had a low precision, at 3.5. Pattern of organ involvement Burkitt lymphoma Africa had a precision at $100 \%$. Medline recalled 27 reports that were not recalled by the Web of Science. Generally it appears that studies that have relied on laparotomies, autopsies and ultrasound have reported a higher abdominal involvement in eBL than those using clinical examination and plain radiographs. This points to the possibility of missed abdominal involvement due to diagnostic techniques. Conclusion: the review confirms that as more Sub Saharan African (SSA) countries incorporate US as a routine investigation in management of eBL, we are likely to see more abdominal disease with or without facial manifestation.
\end{abstract}

Keywords: endemic Burkitt lymphoma; epidemiology; clinical picture; Bukitt's lymphoma in Africa; diagnostic technology

\section{Introduction}

The first publication giving a detailed account of Burkitt's lymphoma (BL) was in 1958. The disease was described by Denis $P$ Burkitt mainly as a sarcomatous jaw tumor affecting African children [1]. The children presented with swollen jaws, mobile teeth distorted from their arch and facial disfigurement but with minimal pain and no detectable lymph nodes except in the presence of infection. Radiographic evidence of an osteolytic process in the alveolar bone of non-involved quadrants was typically seen. The adrenals and kidneys were reported as the most common non facial organs affected [1]. Subsequently a number of publications were published that elucidated the nature of the tumor as a non-Hodgkin's disease, and defined its geographic distribution outside of African lymphoma belt [2-6]. After an African safari, Burkitt reported a pattern of distribution that suggested a vector borne etiology. Plasmodium species transmitted by mosquitoes were highly suspected due to the fact that the areas with highest prevalence of the disease were also hyper endemic for malaria [7]. A viral association between Epstein-barr virus (EBV) and Burkitt's lymphoma was later reported by Epstein et al. in 1965 [8]. Since then the role of malaria in the pathogenesis of $B L$ has been attributed to two potential pathways: reactivation of memory B cells latently infected with EBV by malaria infection and/or suppression of EBV-specific T cell immunity [9].

Over time, the diagnostic criteria for Burkitt's lymphoma have been defined and enunciated. The World Health Organization (WHO) classification delineates several variants of $\mathrm{BL}$, all of which are high-grade B-cell lymphomas that share deregulation of the c-myc oncogene, leading to the characteristic histological and clinical features of BL [10]. These variants include endemic $B L(e B L)$, sporadic $B L(s B L)$, AIDS-associated BL (aBL), and an "atypical or pleomorphic" variant of BL formerly known as "Burkitt-like" lymphomas in the REAL (Revised European-American Lymphoma)

*Corresponding author: Dr. Adriane Kamulegeya, Makerere University College of Health Sciences, 2nd floor Clin Res Bld., Mulago hospital complex, Kampala, Uganda. Tel.: +256712072432; Email: adrianek55@gmail.com

Received 10 April 2015 Revised 12 June 2015 Accepted 22 June 2015 Published 29 June 2015

Citation: Kamulegeya A, Louis M, Oliver $\mathrm{P}$, Jackson O. Changing clinical picture of endemic Burkitt's lymphoma with improved diagnostic technology: A systematic review. J Cancer Res Ther. 2015; 3(6):77-84. DOI:10.14312/20524994.2015-11

Copyright: (c) 2015 Kamulegeya A, et al. Published by NobleResearch Publishers. This is an open-access article distributed under the terms of the Creative Commons Attribution License, which permits unrestricted use, distribution and reproduction in any medium, provided the original author and source are credited. 
classification. The latter variant exhibits greater nuclear pleomorphism than classical $\mathrm{BL}$, with occasional larger lymphoid cells resembling centroblasts [11].

Unfortunately these diagnostic criteria require expensive immunohistochemical staining, cytogenetics and flow cytometry which are prohibitive for many Sub Saharan African countries (SSA) that have the highest prevalence of the disease [12-14]. Additionally, pathology services in these countries often cannot afford to have specialized hematopathologists, leaving it to the general histopathologists to read the biopsies from all anatomical sites. This limitation poses challenges to accurate pathologic diagnosis, and concordance rates between reports from SSA and expert hematopathologists in developed countries range from as low as $32 \%$ to as high as $82 \%$ for $\operatorname{BL}[15,16]$.

On the radiographic front, x-ray machines, ultrasonography (US) and computer tomography (CT) have become increasingly available in SSA, especially in oncology centers. The shift from clinical examination alone to imaging based-diagnosis and staging may have altered the epidemiological picture of BL. Highly sensitive diagnostic methods may have led to a spike in cases at hitherto uncommon anatomical sites especially for eBL [17]. In 1962, Burkitt alluded to the fact that abdominal tumors may be more common than jaw tumors. He clarified that the discrepancy seen in literature may be due transport challenges and lack of experienced personnel at local health centers [7]. Clinically, abdominal involvement is usually recognizable as any or a combination of the following: a tumor mass in one or both loins, an enlarged liver, an epigastric tumor, or bilateral ovarian masses presenting as freely mobile smooth masses in each iliac fossa [7]. Burkitt further emphasized that nearly all children with the disease on laparotomy or autopsy had abdominal disease with the kidney being the most commonly affected organ [7]. However, even before the incorporation of US, a study from Ghana that based on findings during clinical examination, reported an increase in abdominal disease in comparison to facial disease [18].

As more publications reported clinical features of endemic and sporadic BL, a report from Nigeria showed that even those patients with abdominal but no obvious jaw disease had subtle changes on jaw radiographs characterized by effacement of the lamina dura in $72 \%$ of the cases [19]. This finding reinforced the concept that endemic BL was primarily a disease affecting the jaws. On the other hand, sporadic BL was rarely reported to affect the jaws but seen in the abdomen although some reports had noted subtle jaw changes $[4,5,20,21]$. The advent of HIV associated BL that is very similar in its clinical features with sporadic $B L$ shows the stage of B-cell ontotogony at which chromosome rearrangements take place, is an important factor in determining disease variant. In general, chromosomal errors occur during $\mathrm{V}_{\mathrm{H}} \mathrm{D}_{\mathrm{H}_{H}}$ recombination in the presence of EBV (as seen in eBL) but occur later during isotype class switching in the absence of EBV (as seen in $\mathrm{SBL}$ ). As such, HIV is thought to play similar role as malaria does in eBL [22].

As SSA countries develop, and the price of US machines drop, US scanning has become readily available, this has led to less invasive but more sensitive diagnosis of abdominal involvement [23]. Marjerrison et al. [24] reported significant differences in the rates of abdominal disease detected by physical examination compared to US ( $59 \%$ vs $83 \%$, respectively; $P=0.0004)$. However, the challenges radiographers face in detecting $\mathrm{BL}$, especially in the intestines, are substantial [24-26] and this problem is compounded by the existence of many tropical diseases that can cause abdominal organomegaly such as malaria and schistosomiasis [27, 28]. Thus, US unlike laparotomy and autopsy may identify organomegaly due to other tropical diseases and attribute it to BL. However, since laparotomy and autopsy pathological analysis are reported to have demonstrated a high prevalence of abdominal involvement in eBL $[7,29]$, we can safely assume that in the absence of confirmatory US guided biopsy, most of the organomegaly observed is usually due to eBL. This assumption is further supported by the reduction and disappearance of these abdominal symptoms and signs following treatment [19]. Additionally, a study from Cameroon confirmed BL using fine needle aspiration (FNA) after detecting abdominal disease by US in $59 \%$ of the cases [25].

\section{Methods}

The search terms Burkitt lymphoma, Burkitt's lymphoma, and Africa were used to search Medline through the pubmed interface with a combination of any of the following terms, endemic, clinical features, pattern of organ involvement and epidemiology. Selection criteria were then applied to the output from the searches. This was followed by a search and the selected literature reviewed.

We also used the same search terms on the Web of Science accessed through Fred Hutchinson's Arnold library. Web of Knowledge/ science reviews a different selection of journals and also has the "cited reference search" that prospectively identifies all reports within its database that have cited a particular report. Additionally we searched the Directory of Open Access Journals (DOAJ). The search terms were derived from textbooks and journal articles. The search was done in February 2014.

There were five principal inclusion criteria for the selected articles

(a) The study should not be a review article, (b) The study had to represent a complete collection of confirmed cases of Burkitt lymphoma. However, clinical diagnosis was accepted since in the early times, high clinical suspicion index accompanied by good response to treatment in the absence of biopsy results was considered confirmatory for the disease, (c) Case reports were excluded, (d) The study should give some indication as to what investigative procedures were done on the patients included in that particular report, (e) The patient series should not have been reported on in an already selected paper. Information including: country in which the study was conducted, number of cases, year of publication, anatomical sites involved and any special comments from the authors deemed vital were extracted onto a standardized form. Table 1 shows the articles that were included in this review. 
Table 1 Shows the articles chosen for this systematic review.

\begin{tabular}{|c|c|c|c|c|c|c|c|}
\hline Author and publication year & $\begin{array}{l}\text { Country of research } \\
\text { and number of } \\
\text { patients }\end{array}$ & $\begin{array}{l}\text { Diagnostic } \\
\text { method used }\end{array}$ & Facial & $\begin{array}{l}\text { Abdo- } \\
\text { minal }\end{array}$ & $\begin{array}{l}\text { Facial } \\
\text { and Abdo- } \\
\text { minal }\end{array}$ & Other & Comments \\
\hline Burkitt Dennis, 1958 [1] & $\begin{array}{l}\text { Uganda } 38 \\
\text { patients }\end{array}$ & No ultrasound & 78.9 & 2.6 & 15.9 & 2.6 & $\begin{array}{l}\text { Six patients who had autopsy } \\
\text { and } 2 \text { who had laparotomy all } \\
\text { had abdominal disease }\end{array}$ \\
\hline Olson WC et al., 1969 [73] & Congo 15 patients & No ultrasound & 60 & 6.7 & 33.3 & & $\begin{array}{l}\text { One case of thyroid and } \\
\text { abdominal mass was included } \\
\text { in facial and abdominal } \\
\text { category }\end{array}$ \\
\hline Muligan TO, 1971 [74] & Nigeria 65 patients & No Ultrasound & 43.1 & 30.7 & 6.1 & 20.1 & $\begin{array}{l}\text { All except } 4 \text { had biopsy } \\
\text { confirmation of } B L\end{array}$ \\
\hline Wosornu JL et al., 1971 [75] & Ghana 50 patients & No Ultrasound & 56 & 12 & 24 & 8 & $\begin{array}{l}\text { One case with mandibular } \\
\text { and testes included in face } \\
\text { while CNS and intra-thoracic } \\
\text { as others }\end{array}$ \\
\hline Nkurumah F et al., 1976 [2] & $\begin{array}{l}\text { Ghana } 110 \\
\text { patients }\end{array}$ & No Ultrasound & 54.5 & 18.2 & 25.5 & & $\begin{array}{l}\text { Authors state that most } \\
\text { cases with abdominal and } \\
\text { another site the facial area } \\
\text { was commonest so we took } \\
\text { all such cases as abdominal } \\
\text { and facial }\end{array}$ \\
\hline Durodola, 1976 [58] & $\begin{array}{l}\text { Nigeria } 156 \\
\text { patients }\end{array}$ & No ultrasound & 68.9 & 27.6 & 6.4 & 3.8 & $\begin{array}{l}\text { Since } 117 \text { were reported as } \\
\text { facial yet } 107 \text { as stage } 1 \text { and } \\
2 \text { we deduced that } 10 \text { were } \\
\text { both facial and abdominal }\end{array}$ \\
\hline Durodola, 1977 [59] & $\begin{array}{l}\text { Nigeria } 127 \\
\text { patients }\end{array}$ & Laporatomies & 19.8 & 40.5 & 11.2 & 28.4 & $\begin{array}{l}\text { Percentages expressed out of } \\
\text { total as derived from table } 2\end{array}$ \\
\hline Biggar J et al., 1979 [50] & $\begin{array}{l}\text { Ghana } 213 \\
\text { patients }\end{array}$ & No Ultrasound & 42.3 & 34.3 & 22.1 & 1.4 & \\
\hline Olweny et al., 1980 [60] & Uganda & No ultrasound & 35.1 & 35 & 27.9 & & $\begin{array}{l}\text { As per the staging used } \\
\text { combined abdominal and } \\
\text { facial were stage } C \text { but some } \\
\text { intra-abdominal only are } \\
\text { misclassified }\end{array}$ \\
\hline Biggar RJ et al., 1981 [51] & Ghana & No ultrasound & 39.3 & 38.6 & 19.8 & & \\
\hline Kitinya N J et al., 1982 [65] & $\begin{array}{l}\text { Tanzania } 100 \\
\text { patients }\end{array}$ & No ultrasound & 40 & 41 & & 19 & $\begin{array}{l}\text { Details of others were lacking. } \\
\text { Regional differences noted }\end{array}$ \\
\hline Mouden Par JC et al., 1988 [77] & $\begin{array}{l}\text { Cameroun } 66 \\
\text { patients }\end{array}$ & No ultrasound & 29.6 & 50 & 17.2 & & \\
\hline Gadegbeku S et al., 1988 [78] & $\begin{array}{l}\text { Cote-d'Ivoire } 44 \\
\text { patients }\end{array}$ & Ultra sound & 41 & 55 & & 4 & $\begin{array}{l}\text { Ultrasound picked some } \\
\text { abdominal involvement not } \\
\text { picked by clinical examination }\end{array}$ \\
\hline Hesseling et al., 1989 [71] & $\begin{array}{l}\text { South Africa } \\
\text { and Namibia } 22 \\
\text { patients }\end{array}$ & No Ultrasound & 59 & 36.3 & & & \\
\hline Doumbé P et al., 1997 [67] & Cameroon & No ultrasound & 74 & 18 & & 8 & \\
\hline Rafaramino, F et al., 2001 [79] & $\begin{array}{l}\text { Madagascar } 40 \\
\text { patients }\end{array}$ & Ultrasound & 40 & 5 & 48.5 & 7.5 & \\
\hline Oguonu et al., 2002 [69] & Nigeria 44 patients & Ultrasound & 23 & 32 & 35.1 & 9.9 & $\begin{array}{l}\text { US was only done on those } \\
\text { with abdominal tumors so } \\
\text { occult some misclassification } \\
\text { is likely }\end{array}$ \\
\hline Kazembe et al., 2003 [70] & Malawi 92 patients & No ultrasound & 59.8 & 17.8 & 4.8 & & $\begin{array}{l}\text { Although initially } 107 \text { patients } \\
15 \text { were dropped due to } \\
\text { inconclusive FNA results }\end{array}$ \\
\hline Mwanda WO et al., 2005 [57] & Kenya 471 cases & $\begin{array}{l}\text { Ultrasonography } \\
\text { when and as } \\
\text { available }\end{array}$ & 63.5 & 13.4 & 9.3 & & $\begin{array}{l}\text { Varying geographic } \\
\text { anatomical presentation }\end{array}$ \\
\hline Ogwang M, et al., 2008 [55] & $\begin{array}{l}\text { Uganda } 500 \\
\text { patients }\end{array}$ & Ultrasound & 35 & 54 & 2 & & $\begin{array}{l}\text { Authors noted the difference } \\
\text { in clinic-anatomical } \\
\text { presentation with age. Jaw } \\
\text { tumors being seen in very } \\
\text { young patients }\end{array}$ \\
\hline Israëls T, 2009 [44] & Malawi 84 patients & Ultrasound & 31 & 65.5 & & & \\
\hline Orem J et al., 2009 [52] & $\begin{array}{l}\text { Uganda 1,211 } \\
\text { patients }\end{array}$ & $\begin{array}{l}\text { Clinical and } \\
\text { ultrasound }\end{array}$ & 57.6 & 27.1 & 0.321 & & $\begin{array}{l}\text { We introduced similar } \\
\text { misclassification as in Olweny } \\
\text { et al. } 1980[64]\end{array}$ \\
\hline
\end{tabular}




\begin{tabular}{|c|c|c|c|c|c|c|c|}
\hline Stefan et al., 2011 [72] & $\begin{array}{l}\text { South Africa } 45 \\
\text { patients }\end{array}$ & Ultra sound & 15.6 & 75.5 & & 6.6 & \\
\hline Traoré F et al., 2011 [80] & $\begin{array}{l}\text { Burkina-Faso, } \\
\text { Cameroon, Ivory } \\
\text { Coast, Mali, } \\
\text { Madagascar, and } \\
\text { Senegal } 178 \text { cases }\end{array}$ & Ultrasound & 23 & 31.3 & 36.9 & 8.8 & \\
\hline Oluwasola et al., 2011 [81] & $\begin{array}{l}\text { Nigeria } 167 \\
\text { patients }\end{array}$ & Ultrasound & 37.1 & 24.7 & & 6.3 & $\begin{array}{l}14.5 \% \text { were nodal i.e } \\
\text { cervical,inguinal. Authors talk } \\
\text { of improved radiographic } \\
\text { diagnostics thus we inferred } \\
\text { ultrasound use }\end{array}$ \\
\hline Aka P et al., 2012 [64] & $\begin{array}{l}\text { Tanzania } 944 \\
\text { patients }\end{array}$ & No ultrasound & 44.5 & 49.7 & & 5.7 & $\begin{array}{l}\text { Although FNA was rarely } \\
\text { done, response to treatment } \\
\text { is usually a good indicator } \\
\text { of BL }\end{array}$ \\
\hline Lewis N et al., 2012 [66] & $\begin{array}{l}\text { Cameroon } 471 \\
\text { patients }\end{array}$ & Ultrasound & 19.1 & 37.8 & 42.8 & & $\begin{array}{l}\text { The patients included both } \\
\text { FNA confirmed and the strict } \\
\text { clinical criteria for diagnosis } \\
\text { of BL }\end{array}$ \\
\hline Marjerrison S, et al., 2012 [25] & $\begin{array}{l}\text { Cameroon } 95 \\
\text { patients }\end{array}$ & Ultrasound & 16.8 & 21.1 & 56.8 & 5.2 & $\begin{array}{l}\text { Event free survival being } \\
\text { better for those up staged } \\
\text { by US shows that very early } \\
\text { abdominal involved is missed } \\
\text { during clinical examination }\end{array}$ \\
\hline Ngoma T et al., 2012 [82] & $\begin{array}{l}\text { Tanzania, Kenya } \\
\text { and Nigeria } 356 \\
\text { patients }\end{array}$ & Ultrasound & 41.6 & 36.6 & 22.9 & 4.8 & $\begin{array}{l}156 \text { cases underwent } \\
\text { histological re-evaluation and } \\
\text { majority were } B L\end{array}$ \\
\hline Enow-Orock GE et al. 2013 [30] & $\begin{array}{l}\text { Cameroun } 300 \\
\text { patients }\end{array}$ & Ultrasound & 36.7 & 57.7 & & 4.6 & $\begin{array}{l}\text { Surprisingly no combination } \\
\text { of oro-facial and abdominal } \\
\text { reported }\end{array}$ \\
\hline
\end{tabular}

\section{Results}

The search terms and databases identified all but one report that may be relevant to the review, the Enow-Orock et al. [30] report was only identified by searching and

search" did not identify any review reports in addition to those already identified by the search terms and review of the pubmed and the bibliography. Table 2 displays each reviewing the DOAJ. The Web of Science's "cited reference

search term, the total number of reports, the recall and

Table 2 Shows search terms and their yields for the two electronic data bases medline (med) and Web of Science (Wos) used in the systematic review (SR).

\begin{tabular}{|c|c|c|c|c|c|c|c|c|c|c|}
\hline \multirow{2}{*}{ Search terms } & \multicolumn{2}{|c|}{$\begin{array}{l}\text { Total number of } \\
\text { reports }\end{array}$} & \multicolumn{2}{|c|}{$\begin{array}{l}\text { No of reports } \\
\text { included in review }\end{array}$} & \multicolumn{2}{|c|}{ Recall \% } & \multicolumn{2}{|c|}{ Precision \% } & \multicolumn{2}{|c|}{$\begin{array}{c}\text { Bibliography of references included in the } \\
\text { review }\end{array}$} \\
\hline & Med & Wos & Med & Wos & Med & Wos & Med & Wos & Med & Wos \\
\hline $\begin{array}{l}\text { (a) Endemic Burkitt } \\
\text { lymphoma Africa }\end{array}$ & 825 & 65 & 29 & 5 & 90.6 & 16.1 & 3.5 & 7.6 & $\begin{array}{l}{[1,19,25,44,50-52,} \\
55,57,59,60,64-80 \\
82]\end{array}$ & {$[25,52,55,66,81]$} \\
\hline $\begin{array}{l}\text { (b) Clinical features Burkitt } \\
\text { lymphoma Africa }\end{array}$ & 37 & 13 & 6 & 1 & 41.9 & 19.3 & 16.2 & 7.6 & $\begin{array}{l}{[19,50,52,57,59} \\
71]\end{array}$ & {$[52]$} \\
\hline $\begin{array}{l}\text { (c) Pattern of organ } \\
\text { involvement Burkitt } \\
\text { lymphoma Africa }\end{array}$ & 2 & 0 & 2 & 0 & 6.4 & 0 & 100 & 0 & {$[59,71]$} & \\
\hline $\begin{array}{l}\text { (d) epidemiology of Burkitt } \\
\text { lymphoma Africa }\end{array}$ & 482 & 30 & 20 & 4 & 62.5 & 12.9 & 4.1 & 13.3 & $\begin{array}{l}{[25,50-52} \\
55,57,58,64-69,72, \\
73,76-78]\end{array}$ & $52,55,66,81]$ \\
\hline $\begin{array}{l}\text { (e) Endemic Burkitt's } \\
\text { lymphoma Africa }\end{array}$ & 869 & 40 & 27 & 1 & 84.4 & 3.1 & 3.1 & 2.5 & $\begin{array}{l}{[1,19,25,50-52,55} \\
57-59,64-79,82]\end{array}$ & {$[66]$} \\
\hline $\begin{array}{l}\text { (f) Clinical features Burkitt's } \\
\text { lymphoma Africa }\end{array}$ & 42 & 9 & 27 & 1 & 84.4 & 3.1 & 64.3 & 11.1 & $\begin{array}{l}{[1,19,25,44,50-52} \\
55-60,64-70,72-79 \\
80,82]\end{array}$ & {$[52]$} \\
\hline $\begin{array}{l}\text { (g) Pattern of organ } \\
\text { involvement Burkitt } \\
\text { lymphoma Africa }\end{array}$ & 2 & 0 & 1 & 0 & 3.1 & 0 & 50 & 0 & {$[59,71]$} & \\
\hline $\begin{array}{l}\text { (h) epidemiology of Burkitt's } \\
\text { lymphoma Africa }\end{array}$ & 567 & 17 & 6 & 2 & 19.5 & 6.5 & 1.1 & 11.8 & $\begin{array}{l}{[19,50,52,57,59,} \\
71]\end{array}$ & {$[66,81]$} \\
\hline
\end{tabular}

Abbreviations: aRecall was expressed as SR-identified reports for that search term for that database as a percentage of the total number of SR-identified reports, which is 32; ${ }^{b}$ Precision was expressed as SR-identified reports as a percentage of the total number of reports for that search term for that database; 'DOAJ (Directory of open access journals) was not included in this table since it's yield was so low. 
precision for both databases, and the identity of those reports.

Altogether there were 52 reports that appeared to comply with the inclusion criteria, some sets of reports were considered under Criterion $A$ and were eliminated including: Emmaneul B et al. [31], Fleming A [32], Molyneux, Elizabeth $\mathrm{M}$ et al. [33], Orem J et al. [34], Walusansa et al. [35].

Some other reports that initially appeared to be relevant to the review were rejected because they did not give sufficient details on the anatomical distribution of the disease. Amusa et al. [36] did not fully describe the clinical features of all the cases concentrating on the $71.4 \%$ of patients who had head and neck manifestations while Hesseling P et al. (2010) and Ladjadj et al. [37] reported on patients with abdominal disease only. Magrath et al. (1974) [38] did not provide details on the Burkitt's lymphoma distribution concentrating on non Burkitt's disease. Loubiere $\mathrm{R}$ et al. (1975) [39] reported 80\% jaw involvement without giving more details and thus was eliminated. Suvatte et al. [40], Akinwade et al. [3] and Diop et al. [41] also reported on jaw lesions only and thus were excluded. Likewise, a report from Zambia [42] didn't give details of the anatomical distribution of BL just reporting a 56\% jaw involvement and as such was not included. On the other hand, Hesseling et al. (2009) [43] gave details but it was not easy to pick out the different categories like in Israëls T et al. [44] so we took the later since the locality and investigative methods were the same.

The following reports were excluded under Criterion C: Cammoun M et al. [45], Ong SK et al. [46], Sudarsanam T [47], Yagi K I [48]. Although some had more than a case or two, the reports had too few cases to make meaningful contribution to this review. Based on criterion Nkrumah FK et al. $[19,49]$ were not included since we felt the data was double reported by the Nkrumah et al. [2] and Biggar et al. studies $[50,51]$ respectively. Two reports from Uganda, Orem J et al. [52] and Baik S et al. [53] also appeared to have reported on similar patients as Orem J et al. [54] and Ogwang et al. [55] respectively. Likewise Mwanda $O$ et al. [56] was excluded under the same criteria, opting for Mwanda O et al. [57].

Two of the reports of Durodola overlapped [58, 59], but a critical review suggested it was unlikely that 3 years of overlap would result in significant double reporting given the rapidly progressive nature of the disease. Likewise, the Biggar et al. reports $[50,51]$ were included using the same reasoning.

Of the search terms used in Table 2, "endemic Burkitt lymphoma Africa" recalled the most systematic review identified reports overall for Medline, but it had a low precision, which was 3.5. Pattern of organ involvement Burkitt lymphoma Africa had a precision at $100 \%$.

A total of 32 reports survived the selection criteria and were accepted for the review as shown in Table 1. The search term details and their yields are shown in Table 2. Of all the reports included in this review, Medline recalled 27 reports that were not recalled by the Web of Science, whereas the latter didn't identify any report not found in the former.

\section{Discussion}

\section{Changing anatomical sites with use of ultrasound}

Recent reports from SSA have shown different results in terms of the percentages of patients with abdominal involvement. From the cradle of $\mathrm{BL}$, the Uganda Cancer Institute still showed predominant jaw disease (75\%) [54]. US was one of the routine investigations used and it showed that up to $66.7 \%$ had abdominal involvement as well as facial disease. A study from Northern Uganda showed predominance of abdominal involvement (54\%) followed by facial involvement (35\%) with $2 \%$ showing a combination of facial and abdominal presentation [55]. An older study by Olweny et al. [60] that did not rely on ultra sound reported similar findings with Orem et al. [54], with jaw swelling at $72 \%$ and abdominal involvement at $56 \%$ unfortunately they did not provide details as to how many had both facial and abdominal sites of disease. The Ogwang et al. [55] study from N. Uganda showed nearly an equal distribution of $\mathrm{BL}$ by anatomical site as a Turkish study that reported abdominal involvement at $50 \%$ but with nearly an equal number of facial tumors [61]. The results by Ogwang et al. [55] also closely resembled those from a Chinese study that reported abdominal involvement at $46.5 \%$ followed by head and neck (34.9\%) [62]. The regional differences in Uganda may be real but further investigations are necessary since there are notable age differences in the anatomical sites of the disease at presentation. An earlier study had shown a higher prevalence of jaw involvement in the northern part at $57.5 \%$ compared to the Southern Western part of the country with the differences attributed to differences in age of patients at presentation [63]. The northern part of Uganda being the main catchment area for Lacor hospital were Ogwang et al. [55] conducted their study and $\mathrm{UCl}$ being the main catchment area for the Southern part, geographical difference may be real. More research is needed to establish if these are true regional differences and any associated factors that may explain these observations.

In Kenya, combined data showed facial presentation dominating at $63.5 \%$ followed by abdominal at $13.4 \%$ and a combination of the two at $9.3 \%$. However, in the same paper regional differences can be seen with the provincial coastal region predominantly having facial disease while the central province had abdominal disease as the main presentation [57]. Such findings lend credence to possible regional differences as seen in Uganda being similar in East Africa.

A Tanzanian study reported abdominal with or without facial involvement as the predominant presentation at $49.7 \%$ followed by facial alone at $44.5 \%$ [64]. This can be extrapolated as evidence for facial disease predominance. However, a major shortfall of this study was the fact that most of the BL cases were not histologically confirmed but rather based on clinical diagnosis and response to $\mathrm{BL}$ treatment. An older report from the same country showed equal distribution of jaw and abdominal disease [65], but likewise it did not give details on combined jaw and abdominal cases. 
A study from Cameroon [25] corroborated the study by Orem et al. [52] reporting a $72 \%$ prevalence of a combination of abdominal and facial disease with $20 \%$ having abdominal disease only. On the other hand, another study from North West Cameroon [66] reported a preponderance of a combination of facial and abdominal disease but at much lower percentage (42.8\%) followed by abdominal disease only in $37.8 \%$ and facial involvement alone in $19.1 \%$. An earlier study that did not have access to ultrasound reported facial (74\%), abdominal (18\%), and other (8\%) [67]. These differences further illustrate the changing epidemiology of the disease due to ultrasound usage within some SSA countries.

In Ghana the picture is different with a retrospective study reporting facial presentation as the main clinical feature of $\mathrm{BL}$ at $48.3 \%$ followed by the abdominal at $19.6 \%$ then a combination of facial and abdominal at 15.8\% [68]. However, an earlier study had reported facial presentation alone and abdominal only as the most common at 39.3\% and $38.6 \%$ respectively followed by a combination of facial and abdominal at 19.8\% [51]. Looking at these figures it's reasonable to argue that the use of ultrasound has not changed the epidemiology uniformly in SSA countries.

Studies from Nigeria have reported preponderance of abdominal presentation compared to facial. Durodola [59] reported a high prevalence of combined facial and abdominal disease for patients that were stage I and II but mainly abdominal disease for patients with stage III disease. He went on to emphasize the likely change in these statistics if laparotomies became routine. Since ultrasound scanning is able to detect abdominal involvement less invasively, its use would likely change the anatomical sites detected during the investigational phase of $B L$ management. A more recent report by Oguonu et al. [69], reported abdominal as the predominant presentation at $32 \%$ followed by facial at $23 \%$, a shift they attributed to increased use of ultrasound that detected more abdominal disease compared to previous Nigerian studies.

In Malawi Kazembe et al. [70] reported on cases seen between 1991-1997 when ultrasound was not routine and by then $59.8 \%$ were facial, $17.8 \%$ abdominal and $4.8 \%$ a combination of facial and abdominal. However a recent report in which ultrasound was routinely used showed abdominal involvement at $65.5 \%$ and facial only at $31.0 \%$ with up to $21.8 \%$ abdominal disease picked by ultrasound only [44].

A South African study by Hesseling et al. [71] reported 59\% facial involvement equally affecting whites and blacks and $36.3 \%$ as abdominal. However, a more recent report by Stefan et al. [72] reported $71.1 \%$ abdominal involvement and $15.5 \%$ facial involvement. In the report there were differences between HIV positive and negative patients at $53.3 \%$ and $80 \%$ abdominal involvement and facial at $26.7 \%$ and $10 \%$ respectively raising the argument of two different disease entities. Although this may be a valid argument, a change in Burkitt's lymphoma incidence with the advent of HIV/ AIDS is not appreciated across board in SSA.

\section{Conclusion}

Generally it appears that studies that have relied on laparotomies, autopsies and ultrasound have reported a higher abdominal involvement in eBL than those using clinical examination and plain radiographs. This pointed out the possibility of missed abdominal involvement due to diagnostic techniques. Therefore as more SSA countries incorporate US as a routine investigation in management of $B L$, we are likely to see more abdominal disease with or without facial manifestation.

\section{Competing interests}

The authors declare that they have no competing interests.

\section{References}

[1] Burkitt D. A Sarcoma Involving the Jaws in African Children. Br J Surg. 1958; 46(197): 218-223.

[2] Nkrumah F, Perkins IV. Burkitt's lymphoma: a clinical study of 110 patients. Cancer. 1976; 37(2):671-676.

[3] Akinwande J, Odukoya O, Nwoku AL, Taiwo EO. Burkitt's lymphoma of the Jaws in Lagos. Ten-year review. J Maxillofac Surg. 1986; 14(6):323328.

[4] Miyoshi I. Japanese Burkitt's Lymphoma: Clinicopathological Review of 14 Cases. Jpn J Clin Oncol. 1983; 13(3):489-496.

[5] Sandlund JT, Fonseca T, Leimig $T$, Verissimo $L$, Ribeiro $R$, et al. Predominance and characteristics of Burkitt lymphoma among children with non-Hodgkin lymphoma in northeastern Brazil. Leukemia. 1997; 11(5):743-746.

[6] Anaissie E, Geha S, Allam C, Jabbour J, Khalyl M. Burkitt's Lymphoma in the Middle East. Cancer. 1985; 56(10):2539-2543.

[7] Burkitt D. A tumour syndrome affecting children in tropical Africa. Postgrad Med J. 1962; 38:71-79.

[8] Epstein MA, Henle G, Achong BG, Barr YM. Morphological and biological studies on a virus in cultured lymphoblasts from Burkitt's lymphoma. J Exp Med. 1965; 121:761-770.

[9] Rochford R, Cannon MJ, Moormann AM. Endemic Burkitt's lymphoma: a polymicrobial disease? Nat Rev Microbiol. 2005; 3(2):182-187.

[10] Bennett J, Berard C, Butler J. Histopathological definition of Burkitt's tumour. Bull World Heal Organ. 1969; 40:601-607.

[11] Turner JJ, Hughes AM, Kricker A, Milliken S, Grulich A, et al. WHO non-Hodgkin's lymphoma classification by criterion-based report review followed by targeted pathology review: an effective strategy for epidemiology studies. Cancer Epidemiol Biomarkers Prev. 2005; 14(9):2213-2219.

[12] Jaffe ES, Diebold J, Harris NL, Muller-Hermelink HK, Flandrin G, et al. Burkitt's lymphoma: a single disease with multiple variants. The World Health Organization classification of neoplastic diseases of the hematopoietic and lymphoid tissues. Blood. 1999; 93(3):1124.

[13] Sasco AJ, Jaquet A, Boidin E, Ekouevi DK, Thouillot F, et al. The Challenge of AIDS-Related Malignancies in Sub- Saharan Africa. PLoS One. 2010; 5(1):e8621.

[14] Naresh KN, Raphael M, Ayers L, Hurwitz N, Calbi V, et al. Lymphomas in sub-Saharan Africa - what can we learn and how can we help in improving diagnosis, managing patients and fostering translational research? Br J Haematol. 2011; 154(6):696-703.

[15] Lukande R, Wabinga HR, Tumwine LK. Burkitt's lymphoma in Uganda: the role of immunohistochemistry in diagnosis. East Afr Med J. 2008; 85(5):207-212.

[16] Orem J, Sandin S, Weibull CE, Odida M, Wabinga H, et al. Agreement between diagnoses of childhood lymphoma assigned in Uganda and by an international reference laboratory. Clin Epidemiol. 2012; 4:339347.

[17] Ogwang MD, Zhao W, Ayers LW, Mbulaiteye SM. Accuracy of Burkitt lymphoma diagnosis in constrained pathology settings: importance to epidemiology. Arch Pathol Lab Med. 2011; 135(4):445-450.

[18] Slade T, Teesson M, Carragher N, Farrell M. Commentary on Agrawal et al. (2011): Assessing the impact of changes to diagnostic criteria on the estimated prevalence of alcohol use disorders in general population surveys. Addiction. 2011; 106(11):1944-1945.

[19] Nkrumah FK, Perkins IV. Burkitt's lymphoma in Ghana: clinical features and response to chemotherapy. Int J Cancer. 1973; 11(1):19-29. 
[20] Nzeh DA. Importance of the jaw radiograph in diagnosis of Burkitt's lymphoma. Clin Radiol. 1987; 38(5):519-522.

[21] Economopoulos T, Dimopoulos MA, Foudoulakis A, Nikolaidis C, Tsatalas C, et al. Burkitt's lymphoma in Greek adults. A study of the Hellenic co-operative oncology group. Leuk Res. 2000; 24(12):993998.

[22] Queiroga EM, Gualco G, Weiss LM, Dittmer DP, Araujo I, et al. Burkitt lymphoma in brazil is characterized by geographically distinct clinicopathologic features. Am J Clin Pathol. 2008; 130(6):946-956.

[23] Rickinson SAB, Reiter A, Sandlund JT, Kelly GL, Rickinson AB. Burkitt lymphoma: Revisiting the pathogenesis of a virus-associated malignancy. hematology 2007;277-284.

[24] Hamrick-Turner JE, Saif MF, Powers Cl, Blumenthal BI, Royal SA, et al. Imaging of Childhood Lymphoma Assessment by Histologic. Radiographics. 1994;14(1):11-28.

[25] Marjerrison S, Fernandez CV, Price VE, Njume E, Hesseling P. The Use of Ultrasound in Endemic Burkitt Lymphoma in Cameroon. Pediatr Blood Cancer. 2012; 58(3):352-355.

[26] Biko DM, Anupindi SA, Hernandez A, Kersun L, Bellah R. Childhood Burkitt lymphoma: abdominal and pelvic imaging findings. AJR Am J Roentgenol. 2009; 192(5):1304-1315.

[27] Johnson KA, Tung K, Mead G, Sweetenham J. The imaging of Burkitt's and Burkitt-like lymphoma. Clin Radiol. 1998; 53(11):835-841.

[28] Wilson S, Vennervald BJ, Dunne DW. Chronic hepatosplenomegaly in African school children: a common but neglected morbidity associated with schistosomiasis and malaria. PLoS. 2011; 5(8):e1149.

[29] Wilson S, Vennervald BJ, Kadzo H, Ireri E, Amaganga C, et al. Health implications of chronic hepatosplenomegaly in Kenyan school-aged children chronically exposed to malarial infections and Schistosoma mansoni. Trans R Soc Trop Med Hyg. 2010; 104(2):110-116.

[30] Enow-Orock GE, Tchemtchoua B, Koki NP. Burkitt's Lymphoma in Cameroon: A Review of 300 Cases in Two Referral Health Facilities in Yaound'e. African J Pathol Microbiol. 2013; 2:Article ID 235615.

[31] Emmaneul B, Kawira E, Ogwang MD, Wabinga H, Magatti J, et al. African burkitt lymphoma: age-specific risk and correlations with malaria biomarkers. Am J Trop Med Hyg. 2011; 84(3):397-401.

[32] Fleming AF. The epidemiology of lymphomas and leukaemias in Africa-an overview. Leuk Res. 1985; 9(6):735-740.

[33] Molyneux EM, Rochford R, Griffin B, Newton R, Jackson G, et al. Burkitt's lymphoma. Lancet. 2012; 379(9822):1234-1244.

[34] Orem J, Mbidde EK, Lambert B, de Sanjose S, Weiderpass E. Burkitt's lymphoma in Africa, a review of the epidemiology and etiology. Afr Health Sci. 2007; 7(3):166-175.

[35] Walusansa V, Okuku F, Orem J. Burkitt lymphoma in Uganda, the legacy of Denis Burkitt and an update on the disease status. Br J Haematol. 2012; 156(6):757-760.

[36] Amusa YB, Adediran IA, Akinpelu VO, Famurewa OC, Olateju SO, et al. Burkitt's lymphoma of the head and neck region in a Nigerian tertiary hospital. West Afr J Med. 2005; 24(2):139-142.

[37] Ladjadj Y, Philip T, Lenoir GM, Tazerout FZ, Bendisari K, et al. Abdominal Burkitt-type lymphomas in Algeria. Br J Cancer. 1984; 49(4):503-512.

[38] Magrath IT, Ziegler JL, Templeton AC. A comparison of clinical and histopathologic features of childhood malignant lymphoma in Uganda. Cancer. 1974; 33(1):285-294.

[39] Loubiere R, Ette M, Vilasco J, Bonhomme JS, Bureau JP. Burkitt's disease in the Ivory Coast: anatomo-clinical and epidemiology considerations. Ann Anat Pathol (Paris). 1975; 20(5):437-452.

[40] Wood RE, Nortjé CJ, Hesseling P, Mouton S. Involvement of the maxillofacial region in African Burkitt's lymphoma in the Cape Province and Namibia. Dentomaxillofac Radiol. 1988; 17(1):57-60.

[41] Diop L, Medji LA. Survey of Burkitt's tumor (27 cases in Senegal). Bull Soc Med Afr Noire Lang Fr. 1970; 15(3):540-550.

[42] Chintu C, Athale UH, Patil PS. Childhood cancers in Zambia before and after the HIV epidemic. Arch Dis Child. 1995; 73(2):100-104.

[43] Hesseling P, Molyneux E, Kamiza S, Israels T, Broadhead R. Endemic Burkittlymphoma:a28-daytreatmentschedulewith cyclophosphamide and intrathecal methotrexate. Ann Trop Paediatr. 2009; 29(1):29-34.

[44] Israëls T, van de Wetering MD, Hesseling P, van Geloven N, Caron HN $M E$, et al. Malnutrition and neutropenia in children treated for Burkitt lymphoma in Malawi. Pediatr Blood Cancer. 2009; 53(1):47-52.

[45] Cammoun M, Tabbane F, Mourali N, Gherab A. Burkitt's lymphoma in Tunisia. An observation. Arch Anat Pathol (Paris). 1972; 20(2):135-139.

[46] Ong SK, Xue S, Molyneux E, Broadhead RL, Borgstein E, et al. African Burkitt's lymphoma: a new perspective. Trans R Soc Trop Med Hyg. 2001; 95(1):93-96.
[47] Sudarsanam T, Habte D, Asfaw T. Burkitt's lymphoma in Ethiopia. East Afr Med J. 1972; 49(7):502-508.

[48] Yagi KI, Rahman AE sheikh, Abbas EDK, Prabhu SR. Burkitt's lymphoma in the Sudan. Int J Oral Surg. 1984; 13(6):517-527.

[49] Nkrumah FK, Neequaye J, Biggar RJ. Intrathecal chemoprophylaxis in the prevention of central nervous system relapse in Burkitt's lymphoma. Cancer. 1985; 56(2):239-242.

[50] Biggar RJ, Nkrumah FK, Perkins IV. Presenting Clinical Features of Burkitt's Lymphoma in Ghana, West Africa. J Trop Pediatr Environ Child Health. 1979; 25(6):157-161.

[51] Biggar RJ, Nkrumah FK, Neequaye J, Levine PH. Changes in presenting tumour site of Burkitt's lymphoma in Ghana, West Africa, 1965-1978. Br J Cancer. 1981; 43(5):632-636.

[52] Orem J, Maganda A, Mbidde EK, Weiderpass E. Clinical characteristics and outcome of children with Burkitt lymphoma in Uganda according to HIV infection. Pediatr Blood Cancer. 2009; 52(4):455-458.

[53] Baik S, Mbaziira M, Williams M, Ogwang MD, Kinyera T, et al. A casecontrol study of Burkitt lymphoma in East Africa: are local health facilities an appropriate source of representative controls? Infect Agent Cancer. 2012; 7(1):5.

[54] Orem J, Mulumba Y, Algeri S, Bellocco R, Mangen FW, et al. Clinical characteristics, treatment and outcome of childhood Burkitt's lymphoma at the Uganda Cancer Institute. Trans R Soc Trop Med Hyg. 2011; 105(12):717-726.

[55] Ogwang MD, Bhatia K, Biggar RJ, Mbulaiteye SM. Incidence and geographic distribution of endemic Burkitt lymphoma in northern Uganda revisited. Int J Cancer. 2008; 123(11):2658-63.

[56] Mwanda WO, Remick SC, Whalen C. Adult Burkitt's lymphoma in patients with and without human immunodeficiency virus infection in Kenya. Int J Cancer. 2001; 92(5):687-691.

[57] Mwanda WO, Orem J, Remick SC, Rochford R, Whalen C, et al. Clinical charateristics of Burkitt's lymphoma from three regions in Kenya. East Afr Med J. 2005; 82:135-143.

[58] Durodola Jl. Burkitt's lymphoma in Ibadan: response to various chemotherapeutic agents and long-term survivors. J Natl Med Assoc. 1976; 68(4):294-299.

[59] Durodola Jl. Pattern of Organ Involvement in Burkitt's Lymphoma in Ibadan: A Review. J Natl Med Assoc. 1977; 69(5):319-323.

[60] Olweny CL, Katongole-Mbidde E, Otim D, Lwanga SK, Magrath IT, et al. Long-term experience with Burkitt's lymphoma in Uganda. Int J Cancer. 1980; 26(3):261-266.

[61] Cavdar AO, Gözdaşoğlu S, Yavuz G, Babacan E, Unal E, et al. Burkitt's lymphoma between African and American types in Turkish children: clinical, viral (EBV), and molecular studies. Med Pediatr Oncol. 1993; 21(1):36-42.

[62] Bi CF, Tang Y, Zhang WY, Zhao S, Wang XQ, et al. Sporadic Burkitt lymphomas of children and adolescents in Chinese: a clinicopathological study of 43 cases. Diagn Pathol. 2012; 7:72.

[63] Burkitt D, Wright D. Geographical and tribal distribution of the African lymphoma in Uganda. Br Med J. 1966; 1(5487):569-573.

[64] Aka P, Kawira E, Masalu N, Emmanuel B, Brubaker G, et al. Incidence and trends in Burkitt lymphoma in northern Tanzania from 2000 to 2009. Pediatr Blood Cancer. 2012; 59(7):1234-1238.

[65] Kitinya JN, Lauren PA. Burkitt's lymphoma on Mount Kilimanjaro and in the inland regions of Northern Tanzania. East Afr Med J. 1982; 59(4):256-260.

[66] Lewis N, Young J, Hesseling PB, McCormick P, Wright N. Epidemiology of Burkitt's lymphoma in Northwest Province, Cameroon, 2003-2010. Paediatr Int Child Health. 2012; 32(2):82-85.

[67] Doumbé P, Mbakop A, Mboumi MTE, Obama MT, Kago I, et al. Lymphome de Burkitt chez l'enfant au Cameroun: aspects descriptifs et anatomocliniques. Bull du Cancer. 1997; 84(4):379-383.

[68] Owusu L, Yeboah FA, Osei-Akoto A, Rettig T, Arthur FK. Clinical and epidemiological characterisation of Burkitt's lymphoma: an eight-year case study at Komfo Anokye Teaching Hospital, Ghana. Br J Biomed Sci. 2010; 67(1):9-14.

[69] Oguonu T, Emodi I, Kaine W. Epidemiology of Burkitt's lymphoma in Enugu, Nigeria. Ann Trop Paediatr. 2002; 22(4):369-374.

[70] Kazembe P, Hesseling PB, Griffin BE, Lampert I, Wessels G. Long term survival of children with Burkitt lymphoma in Malawi after cyclophosphamide monotherapy. Med Pediatr Oncol. 2003; 40(1):2325.

[71] Hesseling P, Wood RE, Nortjé CJ MS. African Burkitt's lymphoma in the Cape province of South Africa and in Namibia. Oral Surg Oral Med Oral Pathol. 1989; 68(2):162-166.

[72] Stefan DC, Stones D, Newton R. Burkitt lymphoma in South African children: One or two entities? Transfus Apher Sci. 2011; 44(2):191194. 
[73] Olson CW, Smith JH, Testerman N, Bastin JP, Frazer H. Burkitt's tumor in the Democratic Republic of the Congo. Cancer. 1969; 23(3):740-746.

[74] Mulligan TO. Burkitt's lymphoma in Ilesha, Western Nigeria. Br J Cancer. 1971; 25(1):53-61.

[75] Wosornu JL, Nkrumah FK, Perkins IV. Survival Survival of Burkitt's lymphoma patients in Ghana. Br J Cancer. 1971; 25(3):479-486.

[76] Edington GM. The Burkitt lymphoma in the northern savanna of Nigeria. Prog Clin Biol Res. 1981; 53:133-149.

[77] Mouden JC, Durand JP, Garrigue GP. Burkitt's lymphoma in Cameroon. Anatomo-clinical and epidemiologic considerations of 66 cases seen from 1980 to 1986. Bull Soc Pathol Exot Fil. 1988; 81(1):15-23.

[78] Gadegbeku S, Koutouan A, Angoh Y, Assa A, Bouillet DN, et al. Burkitt's disease in the Ivory Coast 1988. Rev Stomatol Chir Maxillofac. 1990; 91 Suppl 1:39-41.

[79] Rafaramino F, Maminirina RAM, Razafindrabe JAB. A spects épidémiologiques du lymphome de Burkitt de I' enfant à Madagascar. Bull soc Pathol Exot. 2001; 94(5):385-388.

[80] Traoré F, Coze C, Atteby J, André N, Moreira C, et al. Cyclophosphamide monotherapy in children with Burkitt lymphoma: a study from the French-African Pediatric Oncology Group (GFAOP). Pediatr Blood Cancer. 2011; 56(1):70-76.

[81] Oluwasola AO, Olaniyi JA, Otegbayo JA, Ogun GO, Akingbola TS, et al. A fifteen-year review of lymphomas in a Nigerian tertiary health care centre. J Heal Popul Nutr. 2011; 29(4):310-316.

[82] Ngoma T, Adde M, Durosinmi M, Githang'a J, Aken'Ova Y, et al. Treatment of Burkitt lymphoma in equatorial Africa using a simple three-drug combination followed by a salvage regimen for patients with persistent or recurrent disease. Br J Haematol. 2012; 158(6):749762. 